\title{
As Origens do Financiamento Industrial no Brasil (1891-1940): um Estudo da Companhia Antarctica Paulista'
}

\section{The Origins of Industrial Financing in Brazil (1891-1940): The Case of Companhia Antarctica Paulista}

\author{
Ellen Fonseca de Assis ${ }^{\mathrm{a}}$ \\ Michel Deliberali Marson ${ }^{\mathrm{a}}$
}

\begin{abstract}
Resumo: O artigo busca observar quais as formas de financiamento que foram predominantes no suporte aos investimentos da Companhia Antarctica Paulista entre 1891 e 1940. Para isso, são coletados e analisados balanços publicados pela empresa no período proposto. Posteriormente, busca-se a análise da evolução da origem dos recursos e indicadores financeiros da companhia. Ao final da pesquisa, é possível concluir que a maior parcela dos recursos necessários à expansão da empresa foi obtida por meio do mercado de capitais entre o final do século XIX e o final dos anos 1910, com os recursos próprios ganhando importância ao longo dos anos 1920. O mercado de capitais voltou a crescer em participação nos anos 1930.
\end{abstract}

Palavras-chave: Financiamento. Desenvolvimento econômico. Companhia Antarctica Paulista. São Paulo. Mercado de capitais.

\begin{abstract}
This paper aims to observe which form of financing was predominant in the support to the investments of Companhia Antarctica Paulista between 1891 and 1940. In this way, balance sheets published by the company were analyzed during the proposed period. Subsequently, we sought to analyze the evolution of the company's liabilities and financial indicators. At the end of the research, it was possible to conclude that the largest portion of the resources needed to expand the company was obtained through capital markets and own resources.
\end{abstract}

Keywords: Financing. Economic development. Companhia Antarctica Paulista. São Paulo. Stock exchange.

JEL Classification: N26; N66; N86.

1 Este trabalho foi realizado com apoio da Coordenação de Aperfeiçoamento de Pessoal de Nivel Superior - Brasil (CAPES) - Código de Financiamento 001. Agradecemos aos comentários e sugestões dos participantes do IX Encontro de Pós-Graduação em História Econômica e $7^{\text {a }}$ Conferência Internacional de História de Empresas, em Ribeirão Preto, em 2018; do $46^{\circ}$ Encontro Nacional de Economia da ANPEC, no Rio de Janeiro, em 2018; do $6^{\circ}$ Workshop de História Econômica no Insper, em São Paulo, em 2019; do XIII Congresso Brasileiro de História Econômica e 14a. Conferência Internacional de História de Empresas, em Criciúma, em 2019; e também aos pareceristas da revista.

a Universidade Federal de Alfenas (UNIFAL-MG), Instituto de Ciências Sociais Aplicadas (ICSA). Varginha, Minas Gerais, Brasil. 


\section{1 lntrodução}

O financiamento do processo de industrialização e o desenvolvimento econômico são temas centrais para a literatura sobre história econômica financeira. Desde meados dos anos 1950, o foco do financiamento da indústria tem oscilado entre a importância das instituições financeiras, principalmente bancos, na análise seminal de Gerschenkron (1962), e o mercado financeiro como um todo, proposta por Goldsmith (1969). Mais recentemente, vários trabalhos a nível macro tendo como foco países e seus sistemas financeiros foram elaborados com o objetivo de entender qual sistema de financiamento (mercado de ações ou bancos) contribui mais para o desenvolvimento econômico (LEVINE; ZERVOS, 1998; ROUSSEAU; WACHTEL, 1998; BECK; DEMIRGÜÇ-KUNT; LEVINE, 1999; LEVINE LOAYZA; BECK, 2000; BECK; LEVINE; LOAYZA, 2000; DEMIRGÜÇ-KUNT; LEVINE, 2001; FOHLIN, 2012; GAMBACORTA; YANG; TSATSARONIS, 2014; LAW; SINGH, 2014; FOHLIN, 2016). Entretanto, a questão das fontes de financiamento tem sido pouco explorada pela área de história de empresas, e estudos de casos poderiam ajudar a entender a relação entre as fontes de financiamento e o desenvolvimento industrial. ${ }^{2}$

O estudo da configuração das instituições financeiras nos primeiros estágios de desenvolvimento de um país se mostra especialmente relevante, pois permite compreender o processo de transição de uma economia de base primário-exportadora para uma economia industrial, como o Brasil entre o final do século XIX e o início do século XX (HANLEY, 2005, p. 116). No entanto, as formas de financiamento que contribuíram para o suporte dessa indústria nascente ainda é uma questão pouco explorada e controversa na história econômica do Brasil. Nesse sentido, observa-se que se sustenta uma lacuna em relação à compreensão da evolução do financiamento da produção industrial de bebidas, especialmente de cerveja brasileira entre o fim do século XIX e início do século XX (MARQUES, 2005, p. 88).

De maneira mais específica, o estado de São Paulo, como importante destaque de dinamismo econômico no período, atraiu vários estudos que visaram compreender sua evolução industrial. ${ }^{3}$ Essas pesquisas buscaram entender como a região se apresentou como centro industrial no país já no fim da Primeira Guerra Mundial. As abordagens desses estudos, no entanto, se concentraram em analisar como o nível de investimento no setor industrial era afetado por questões relacionadas à atividade cafeeira, influência do capital externo, guerras ou crises econômicas. Por conseguinte, eles não evidenciaram como os recursos advindos do setor agrícola puderam ser direcionados para o investimento industrial (HANLEY,

2 Apesar da escassez de trabalhos sobre o assunto, especialmente para a indústria cervejeira, foco do artigo, outros trabalhos abordaram o tema para setores específicos da indústria, como os de Versiani e Versiani (1977), Levy (1994), Haber (1992), Haber (1997) e Marson (2015).

Dentre esses estudos, podem ser citados especialmente os de Dean (1971) e Cano (1975). 
2005, p. 116). Na mesma linha de análise, Cortes, Marcondes e Diaz (2014, p. 192) explicaram que estudos ligados ao desenvolvimento financeiro inicial no Brasil também não estabeleceram uma conexão direta com o setor industrial emergente.

O estudo da relação entre a oferta de financiamento e o desenvolvimento da indústria brasileira enfrenta limitações, que de certa maneira, cooperam para a escassez de pesquisas nessa área. As principais barreiras se concentram nas dificuldades teóricas e de obtenção de dados no período. Essas características tendem a dificultar a avaliação empírica dos fatores que contribuíram para o aumento da oferta de financiamento para a indústria em seu período inicial (CORTES; MARCONDES; DIAZ, 2014, p. 191-192; MARQUES, 2005, p. 116).

A partir dessa perspectiva, este trabalho visa contribuir com a historiografia da formação da indústria brasileira. Mais especificamente, o estudo se propõe a analisar a origem dos recursos que financiaram os investimentos na Companhia Antarctica Paulista no período entre 1891 e 1940. A pesquisa foi realizada a partir da análise de fontes primárias. Dessa maneira, foram utilizadas demonstrações contábeis da empresa publicadas no período, as quais foram obtidas no Diário Oficial do estado de São Paulo. Posteriormente, os dados referentes às contas do balanço patrimonial foram organizados em tabelas (ver Anexo A) para a análise da origem de recursos. A interpretação desses dados possibilita avaliar a variação e predominância das fontes de recursos disponibilizados para a companhia no decorrer do tempo, assim como o perfil do financiamento de seu ativo.

Depois desta introdução, a segunda seção do artigo apresenta as diferentes perspectivas dos autores em relação às formas de financiamento que podem ter contribuído para o investimento industrial em seu período emergente. Na terceira seção, é apresentada uma breve introdução do papel da Companhia Antarctica Paulista no segmento industrial de bebidas. A quarta seção realiza a análise do balanço patrimonial da empresa, suas fontes de financiamento e a discussão dos resultados da pesquisa. Por fim, a quinta seção traça as considerações finais.

\section{Debate em Relação às Fontes de Financiamentos da Indústria Brasileira entre o Fim do Século XIX e o Início do Século XX}

Dentre a literatura existente, pode-se observar estudos que identificam diferentes linhas de financiamento que possam ter contribuído de maneira efetiva para a promoção do segmento industrial emergente. Dentre elas, se destacam o financiamento por meio de ações negociadas em bolsa, debêntures, empréstimos bancários e hipotecas. No decorrer desta seção, serão evidenciadas as distintas visões de autores em relação a cada uma delas.

Haber (1997) fez um resumo das formas que o empreendedor pode aplicar o capital para o investimento industrial. Para esse autor, existem cinco formas de 
financiamento do investimento industrial. A primeira forma é por meio de empréstimos de familiares ou conhecidos. Esses empréstimos têm o inconveniente de limitar o investimento à riqueza da rede social do empreendedor, além da responsabilidade pessoal sobre os débitos, caso o empreendimento não tenha sucesso. Essa última característica pode ser eliminada pela segunda forma de financiamento, com a formação de uma sociedade com familiares ou conhecidos. Entretanto, esse segundo tipo também é limitado pela riqueza da rede social do empreendedor. A terceira forma é por reinvestimentos de lucros de um empreendimento existente. O limitador dele é o montante de lucros dos anos anteriores. A quarta forma é através de empréstimos de uma fonte institucional, como bancos ou mercado de títulos. Nesse caso, o empreendedor ainda é responsável legalmente pelos débitos, caso ocorra falência do empreendimento. O problema da responsabilidade sobre os débitos pode ser resolvido pela quinta forma de financiamento, com a venda de uma parte do capital próprio (ações) de um empreendimento para um investidor por negociação pública, geralmente uma bolsa de valores, de uma companhia de sociedade por ações, com responsabilidade limitada à parte do capital adquirido. Uma sociedade por ações também pode vender títulos de dívida (debêntures). A vantagem dessa última forma é a capacidade de mobilizar uma grande quantidade de capital rapidamente e diluir o risco do investimento entre um grande grupo de investidores (HABER, 1997, p. 149-150).

Hanley (2001) destacou a importância da bolsa de valores ${ }^{4}$ para o financiamento das empresas industriais de médio e grande porte em São Paulo no início do século XX. A partir de seu estudo, a autora concluiu que "[...] o financiamento da indústria de São Paulo era um fenômeno local e a Bolsa foi o seu principal veículo [...]” (HANLEY, 2001, p. 134). Nesse sentido, em um cenário no qual há indícios de que as instituições bancárias tiveram escassa participação no direcionamento de recursos para empréstimos de longo prazo, as fontes de financiamento para empresas parecem ter ficado a cargo do mercado de títulos. Por conseguinte, a bolsa teria participado de forma direta na promoção de novos capitais nos segmentos de serviços de utilidade pública e empresas industriais. O fornecimento desses recursos foi de fundamental importância para essas fábricas, visto que estas demandavam grande volume de fundos financeiros, que não poderiam ser disponibilizados por grupos familiares. Dessa maneira, ainda que a Bolsa de São Paulo tenha apresentado apenas um breve período de intensificação de atividades depois de 1909, esse episódio foi suficiente para sustentar investimentos nas empresas financiadas por ela. Dessa forma, a Bolsa de São Paulo foi capaz de gerar

$4 \quad$ A Bolsa em São Paulo foi organizada institucionalmente em 1890, por um grupo de corretores de ações liderado por Emílio Rangel Pestana, e dissolvida em 1892, quando estourou a bolha do Encilhamento. A Bolsa foi reorganizada em 1895 e passou a operar continuadamente desde então (HANLEY, 2001, p. 121-122; HANLEY, 2004, p. 193). 
uma importante contribuição para o desenvolvimento econômico de longo prazo (HANLEY, 2001, p. 134).

Na mesma linha de análise, Musacchio (2009) observou que a bolsa de valores no Brasil desenvolveu um importante mercado entre 1890 e 1913. Com os recursos bancários mais concentrados em empréstimos de curto prazo, direcionados para a provisão do complexo exportador cafeeiro, a bolsa teria sustentado largamente o financiamento da indústria brasileira. No entanto, o mercado de ações e títulos somente pôde cumprir seu papel central no fomento de recursos para a indústria porque havia fatores que possibilitaram atrair acionistas e credores. Além de condições macroeconômicas favoráveis, as configurações dos estatutos das empresas brasileiras garantiam maior proteção aos investidores, restringido os reflexos da má gestão ou abusos da gerência sobre esses agentes. Adicionalmente, foram estabelecidas leis de falência, que garantiam prioridade de recebimento aos debenturistas em cenários de insolvência (MUSACCHIO, 2009, p. 67).

Partindo de outra abordagem, os trabalhos de autores como Triner (1996), Marques (2005), Saes e Szmrecsányi (1995) evidenciaram a importância do papel dos bancos no financiamento de empresas brasileiras no período compreendido entre o fim do século XIX e início do século XX. A partir da perspectiva desses estudos, a abrangência do sistema financeiro é capaz de explicar a evolução e o nível de crescimento econômico alcançado em períodos posteriores.

Triner (1996) identificou o fortalecimento da relação entre a economia produtiva e as instituições financeiras no período entre 1906 e 1930. Sobretudo, sua pesquisa apontou no sentido da formação de um sistema financeiro mais consolidado do que considera a literatura existente. Como indicador desse processo, foi observado o rápido aumento da oferta de meios de pagamento sob a forma de depósitos bancários no período analisado. A elevação do número de aplicações financeiras também demonstrou o aumento da confiança dos depositantes na solidez dessas instituições. Esse fenômeno teria contribuído para aumentar a capacidade de empréstimos ofertados por essas instituições bancárias. Ainda que no Brasil essa ligação não tenha se consolidado de maneira tão significativa, foi observado que o nível de crédito aumentou de forma mais que proporcional em relação ao volume de depósitos no período analisado pela autora (TRINER, 1996, p. 135-136).

Portanto, o estudo de Triner (1996) ofereceu relevantes indícios referentes à existência de relação entre o sistema bancário e o crescimento industrial. A partir dessa análise, as instituições bancárias foram capazes de se desenvolver de forma paralela aos segmentos monetários e reais da economia no período da Primeira República. Esse processo de amadurecimento permitiu ao sistema financeiro aumentar sua robustez, garantindo a atuação eficiente na intermediação e no direcionamento do capital agrícola para o capital industrial (TRINER, 1996, p. 150). 
Sob uma abordagem semelhante, o trabalho de Saes e Szmrecsányi (1995) buscou traçar as características da evolução do sistema bancário paulista entre 1880 e $1930 . .^{5}$ Os autores analisaram a ligação entre os bancos estrangeiros e o segmento industrial no estado. O estudo identificou que os anos de expansão da participação dos bancos estrangeiros na economia coincidiram com o período inicial de aceleração da indústria paulista. Nesse sentido, os autores citaram o exemplo da contribuição expressiva feita pelo London $\mathcal{E}$ Brazilian Bank para a rede de indústrias Matarazzo. Além disso, foram observadas relações próximas do banco com outras empresas paulistas, como a Companhia Nacional de Tecidos de Juta, de propriedade de Jorge Street. As ligações entre o London 83 Brazilian Bank e empresas industriais reforçaram evidências de que a participação dessas instituições financeiras no setor produtivo não se apresentou como um evento isolado. A partir dessa perspectiva, os bancos estrangeiros parecem ter tido um papel fundamental para o desenvolvimento e financiamento da indústria nascente de São Paulo (SAES; SZMRECSÁNYI, 1995, p. 240-241).

Sob uma análise mais específica, Marques (2005) direcionou seu estudo para a trajetória da cervejaria Brahma ${ }^{6}$ e os mecanismos de financiamento de seu plano de expansão. Nesse sentido, a autora observou como uma empresa de pequeno porte, fundada em 1888, obteve recursos para ser ampliada e, já na década seguinte, conquistar grande parcela do mercado doméstico.

No período de sua evolução inicial, o estudo de Marques (2005) revelou que a Brahma mostrou significativos vínculos com o Brasilianische Bank für Deutschland. Sob essa perspectiva, o caso da cervejaria mostrou particularidades em relação às estratégias de crescimento corriqueiramente utilizadas por estabelecimentos industriais na década de 1890, já que "[...] em torno da empresa gravitavam bancos estrangeiros e empresas exportadoras, formando-se uma comunidade de negócios onde os dirigentes da Brahma encontraram financiamento para ampliar a empresa [...]" (MARQUES, 2005, p. 88).

No entanto, essa rede não se formou a partir dos princípios de solidariedade, ou mesmo, simpatia, mas pelas próprias relações contratuais e alterações na legislação comercial. Nesse sentido, essas mudanças foram fundamentais, pois ofereciam o aumento de garantias aos detentores de debêntures e, consequentemente, forneceram incentivos para a elevação da oferta desse tipo de financiamento. A partir desse cenário, o banco Brasilianische Bank für Deutschland estreitou suas relações com a Brahma. Inicialmente, a instituição adquiriu os títulos de dívida disponibilizados pela empresa e, a partir de 1904, se tornou acionista da cerveja-

5 Os autores escolheram esse período pela intensificação da presença dos bancos estrangeiros no sistema bancário da região, além da rápida transição de São Paulo como o principal centro industrial do país.

6

Para ler outros estudos da autora sobre a indústria de cerveja, ver Marques (2014) e Marques (2015). 
ria. Contudo, o envolvimento do banco com a Brahma parece que esteve ligado à política alemã de criação de zonas para a comercialização de produtos do país frente à concorrência de mercadorias inglesas (MARQUES, 2005, p. 88).

No caso específico da Brahma, os bancos vinculados à rede de negócios alemães não tinham como objetivo principal o fomento de atividades industriais no Brasil. Dessa maneira, nem as antecipações em contas da empresa, como créditos renováveis, foram suficientes para sustentar o nível de investimento demandado pelo processo de expansão da cervejaria. Nesse sentido, o papel do banco Brasilianische estava na compra de debêntures da empresa e a promoção de maior liquidez a esses títulos, visto que atuou na intermediação da venda desses papéis junto a investidores. Consequentemente, é provável que essa tenha sido a principal contribuição da instituição bancária para o desenvolvimento da cervejaria. Em outras palavras, os bancos que atuavam no mercado brasileiro "[...] não estavam guiados pelo propósito de aprofundar a presença na economia, criando raízes no sistema produtivo doméstico [...]" (MARQUES, 2005, p. 103).

Partindo de outra perspectiva, Cortes, Marcondes e Diaz (2014) demonstraram que o processo de industrialização do Brasil foi fortemente consolidado por um período de intenso crescimento do mercado de crédito hipotecário (CORTES; MARCONDES; DIAZ, 2014, p. 195-196). Na mesma linha de estudo, outro trabalho de Marcondes e Hanley (2010) destacou que essa forma de financiamento se mostrou mais relevante e abrangente do que demonstraram outras pesquisas relacionadas ao desenvolvimento bancário e econômico brasileiro (MARCONDES; HANLEY, 2010, p. 104). Contudo, vale ressaltar que os créditos baseados em hipotecas já eram concedidos no período colonial. Porém, a ausência de um registro hipotecário dificultava ao credor a tarefa de certificar-se que o mesmo imóvel já não tivesse sido oferecido como garantia em outros empréstimos. Além disso, a solução de conflitos e o cumprimento de contratos estavam sujeitos a longos processos judiciais, o que aumentava consideravelmente o prazo de reembolso desses agentes. Esses fatos contribuíam para o aumento da desconfiança em relação à solidez do tipo de proteção oferecida pelos devedores, desestimulando a oferta dessa modalidade de financiamento (BRITO, 1923, p. 107 apud MARCONDES, 2014, p. 752).

A expansão da oferta de crédito hipotecário ocorreu no interior de um cenário de reformas institucionais que permitiram o crescimento desse tipo financiamento no Brasil e o aumento de garantia para os credores (CORTES; MARCONDES; DIAZ, 2014, p. 195-196). Dentro desse contexto, Marcondes e Hanley (2010) explicaram a relevância da implementação do Código Comercial em 1850. Embora elaborado com o foco voltado para operações relacionadas à comercialização de produtos primários, esse conjunto de diretrizes permitiu a regulamentação de operações bancárias e o consequente aumento da oferta de crédito comercial. Adicionalmente, a Lei de Terras, de 18 de setembro de 1850, representou um pon- 
to de inflexão no estabelecimento dos direitos de propriedade, indispensáveis para a operação de empréstimos hipotecários. ${ }^{7}$ Foi observada também a criação de duas outras regulamentações, que possuíam diretrizes mais específicas: as Leis Hipotecárias, de 1864 e 1890, que estimularam o financiamento de longo prazo, e as Leis Empresariais, de 1882 e 1890, que viabilizaram a constituição de instituições bancárias por meio de sociedades anônimas (MARCONDES; HANLEY, 2010, p. 107). Dessa maneira, Cortes, Marcondes e Diaz (2014) relataram que os empréstimos por hipoteca se iniciaram de forma mais significativa a partir de $1866 \mathrm{e}$ alcançaram maior difusão após 1870. A partir desse período até a Primeira Guerra Mundial, observou-se um sustentado crescimento da oferta dessa modalidade de financiamento (CORTES; MARCONDES; DIAZ, 2014, p. 201).

Os empréstimos hipotecários representaram uma nova alternativa de fomento para a atividade produtiva, visto que diversos agentes viram nesse tipo de crédito a maneira de garantir a proteção de seus recursos. Essa modalidade de financiamento não se restringiu ao segmento bancário, tendo a participação expressiva de capitalistas, negociantes e, até mesmo, comerciantes. Embora organizações de maior porte ${ }^{8}$ buscassem financiamentos por meio da venda de ações, uma parcela desses títulos apresentava como garantia propriedades imobiliárias pertencentes às empresas registradas em hipotecas, de maneira que:

[...] o mercado hipotecário mostrou-se mais amplo do que o crédito imobiliário rural ou urbano, compreendendo muitas vezes o comercial e até mesmo o industrial. Por fim, alguns lançamentos de debêntures que procuravam melhores garantias para o credor também se fizeram por meio de hipotecas (MARCONDES, 2014, p. 757).

Por meio da análise descritiva de dados, Cortes, Marcondes e Diaz (2014) encontraram evidências de que o crédito hipotecário se mostrou fundamental para o fomento do desenvolvimento paulista e o estágio inicial de sua industrialização: grande parcela das negociações envolvendo o crédito industrial ocorreu fora do sistema bancário, sendo guiadas por outros agentes domésticos (como homens de negócios e capitalistas), e as hipotecas e a importação de máquinas e equipamentos foram importantes proxies para o financiamento industrial (CORTES; MARCONDES; DIAZ, 2014, p. 193). Nesse sentido, observou-se uma correlação positiva entre os empréstimos hipotecários e as importações de máquinas no período. A partir dessa constatação, o nível de importação desses bens de capital pôde ser utilizado como um importante indicador do comportamento do investimento industrial. Dessa maneira, o aumento do investimento na compra de equipamen-

\footnotetext{
$7 \quad$ Segundo Cortes, Marcondes e Diaz (2014), tradicionalmente, antes da implementação da Lei, as terras poderiam ser distribuídas ou, até mesmo, apropriadas de forma livre, estimulando disputas e conflitos violentos.

8 Marcondes (2014) cita o exemplo de empresas ferroviárias.
} 
tos no exterior sinalizava maior propensão, por parte dos empresários, para a ampliação e/ou modernização do setor produtivo.

Para analisar o perfil dessa modalidade de crédito em São Paulo, Cortes, Marcondes e Diaz (2014) coletaram dados de 531 hipotecas firmadas para empresas industriais da região no período de 1866-1914. A partir da análise dos documentos, os autores concluíram que, em 1907, os empréstimos hipotecários industriais chegaram a representar em média 65\% do capital das principais empresas manufatureiras paulistas. Além disso, o desenvolvimento do crédito hipotecário na região sugere sua relação com as mudanças institucionais apresentadas no período (CORTES; MARCONDES; DIAZ, 2014, p. 197-200).

No início do século XX, ainda em um contexto de recessão econômica e decorrente queda do nível de depósitos bancários, a redução no número de hipotecas foi considerada pouco expressiva. Esse fato ofereceu indícios de que os bancos não eram os únicos a oferecer recursos financeiros no mercado hipotecário. Em contrapartida, outros agentes, além dos banqueiros, como os capitalistas, corretores de seguros e homens de negócios, contabilizavam aproximadamente 36,8\% do número de empréstimos direcionados à indústria. Embora firmassem menor quantidade de contratos, esses credores participavam de investimentos de maior porte e, por isso, chegaram a prover 83,3\% do montante de recursos envolvidos nessa modalidade de financiamento (CORTES; MARCONDES; DIAZ, 2014, p. 197-205).

Em relação ao tipo de ativo oferecido como garantia dos empréstimos, havia a predominância de propriedades urbanas. Em outras palavras, grande parte dos imóveis hipotecados eram casas, prédios e terrenos, representando 55,8\% dos contratos. Em segundo lugar, as propriedades rurais, como sítios e chácaras, correspondiam a 22,1\% dos casos, seguido de oficinas e fábricas $(5,2 \%)$, olarias $(1,7 \%)$, fazendas (1,5\%) e armazéns (1,7\%) (MARCONDES; HANLEY, 2010, p. 118).

Ao final de seu estudo, Cortes, Marcondes e Diaz (2014) sugeriram que as principais firmas, em 1907, estavam significativamente envolvidas com o mercado de hipotecas. ${ }^{9}$ Além disso, com base em um modelo econométrico, ${ }^{10}$ os autores concluíram que essa modalidade de financiamento teve uma expressiva relação com os investimentos industriais (CORTES; MARCONDES; DIAZ, 2014, p. 205).

Depois desta seção fazer um balanço dos principais pontos do debate da historiografia econômica sobre as fontes de financiamento industrial, a próxima seção atenta para a descrição da indústria de cerveja e a da Companhia Antarctica Paulista.

9 Cortes, Marcondes e Diaz (2014) utilizam como exemplo o caso do setor têxtil, considerado a indústria mais importante do Brasil no período, em que a relação entre empréstimos hipotecários e o capital total foi de $96 \%$. Em outros setores observados, essa razão girou em torno de $65 \%$.

10 Cortes, Marcondes e Diaz (2014) avaliaram a relação entre o crédito obtido por meio de hipotecas e a importação de máquinas. Dessa maneira, os autores realizaram testes empíricos fundamentados em cointegração. A importação de maquinários foi utilizada como variável proxy, visto que seu nível se constitui em um indicador de investimento. 


\section{A Indústria Cervejeira e a Companhia Antarctica Paulista}

Há vários trabalhos que estudaram as origens e evolução da indústria brasileira, em especial Simonsen (1939), Prado Júnior (1959), Luz (1961), Baer (1966), Dean (1971), Fishlow (1972), Villela e Suzigan (1973), Cano (1975), Silva (1976), Versiani e Versiani (1977), Stein (1979), Cano (1985), Levy (1994), Suzigan (2000) e Marson (2017). O objetivo desta seção é descrever apenas o setor de bebidas, de cerveja em especial, do qual faz parte a empresa estudada no artigo.

O período do início da produção de cerveja no Brasil é indeterminado, mas há indícios de que foi após a Independência. O desenvolvimento do setor foi lento nos primeiros 50 anos, já que há notícias de alguns poucos estabelecimento produtores de cerveja no Rio de Janeiro, São Paulo e Rio Grande do Sul, geralmente como pequena manufatura e instalações simples. Esse cenário mudou a partir das décadas de 1860 e 1870, quando o setor teve grande expansão até os anos 1930, com exceção do período da Primeira Guerra Mundial, marcado por anos de crise devido à dificuldade de importação de insumos (malte e lúpulo), essenciais à produção nacional. Nas décadas de 1870 e 1880, surgiram as primeiras cervejarias industrializadas no Brasil promovendo grande substituição das importações de cervejas da Inglaterra e da Alemanha. Na década de 1890, o governo aumentou o imposto de importação de cerveja, estimulando a produção nacional e eliminando a importação em massa (KÖB, 2000, p. 32-34).

O setor cervejeiro representou um importante segmento de produção no período inicial do desenvolvimento da indústria no Brasil. No início do século XX, as cervejarias já se destacavam pelos altos investimentos direcionados para seu processo produtivo, perdendo apenas para a indústria têxtil de algodão e de açúcar. Dentre outros tipos de bebidas produzidas no país, a cerveja também se destacava no maior nível de valor agregado. Esse produto representava em média $74 \%$ do valor total das bebidas produzidas no Brasil, entre 1911 e 1913, e 73,1\% em 1919 (SUZIGAN, 2000, p. 228).

Originalmente, a produção de cerveja consistia em um processo simples, que não exigia altos montantes de investimento em máquinas e equipamentos. Dessa maneira, as primeiras fábricas foram de pequeno porte e tinham o estilo de produção artesanal. Nesse tipo de estrutura mais rudimentar, a cerveja produzida era do tipo leve e de alta fermentação. Por sua fabricação ser considerada acessível a pequenos produtores, esse ramo se desenvolveu no Brasil antes mesmo do período da Primeira República. Nesse sentido, observou-se que "[...] em finais da década de 1870 existiam no Império pelo menos 18 fábricas de cerveja produzindo de 8 a 10 milhões de garrafas de cerveja anualmente [...]" no Rio de Janeiro (LAGO et al., 1979, p. 15 apud VERSIANI, 1982, p. 470). Na década de 1870, por exemplo, a quantidade produzida por pequenos fabricantes já alcançava 66,7 milhões de 
litros. O grande volume de produção na época foi suficiente, inclusive, para reduzir a demanda por cerveja importada (SUZIGAN, 2000, p. 229).

As décadas de 1880 e 1890 marcaram o início da consolidação de cervejarias de maior porte. Essa nova etapa da produção da bebida teve importante participação de empresários imigrantes, sobretudo alemães. Esses industriais foram capazes de produzir em grande escala a cerveja do tipo alemã. A variedade de bebida leve, anteriormente importada, já havia conquistado a preferência de consumidores brasileiros. Para a produção dessa cerveja no Brasil, os imigrantes importavam máquinas, matérias-primas, como o malte e o lúpulo, e traziam técnicos da Alemanha. Dessa forma, antes mesmo do início do século XX, a demanda pela bebida no Brasil foi praticamente satisfeita pela produção doméstica. As novas empresas obtiveram êxito em produzir as cervejas leves, de ampla variedade. Além de agradar o mercado brasileiro, a produção desse tipo de bebida foi capaz de aumentar o volume de vendas das novas cervejarias (SUZIGAN, 2000, p. 234).

Dentre as grandes empresas produtoras de cerveja que surgiram após 1880 , estava a Companhia Antarctica Paulista. A empresa foi fundada em 1888, a partir de uma sociedade entre o cervejeiro de origem alemã, Louis Bücher, e Joaquim Salles. O segundo sócio era proprietário de uma fábrica de gelo e derivados da carne de porco. Dessa maneira, Joaquim Salles já possuía em sua fábrica um ambiente favorável à produção da bebida, como água potável e estruturas de refrigeração para seu armazenamento. Louis Bücher, ao propor a sociedade, estava interessado na produção de cerveja de baixa fermentação. Como comentado anteriormente, essa bebida diferia, na época, daquelas fabricadas no país, as quais eram de alta fermentação e produzidas de maneira artesanal. Sob essa perspectiva, a cerveja de baixa fermentação, além de ser considerada de qualidade superior, passava pelo processo de pasteurização, o que conferia maior durabilidade à cerveja. Esses fatores contribuíram para o destaque da cervejaria no mercado nacional (KÖB, 2000; SANTOS, 2004; SEMENICHIN, 2006).

A companhia organizou-se como sociedade anônima em 1891, com um capital de 3.000 contos de réis, tomando conta da fábrica Antarctica e do ativo e passivo da firma Joaquim de Salles $\mathcal{E}$ Comp. Uma grande parte das ações foi adquirida por empresários locais. ${ }^{11}$ No entanto, integrava o quadro de acionistas dois brasileiros naturalizados: João Carlos Antônio Frederico Zerrenner, de origem alemã, e Adam Ditrik von Büllow, de origem dinamarquesa, os quais exerceriam importantes funções no processo de expansão da empresa, já que assumiram o seu controle $^{12}$ (com 51,15\% do capital) após a crise financeira e cambial que levou a

11 A primeira diretoria (em 1891) foi composta pelos acionistas Dr. Augusto da Rocha Miranda (presidente), Dr. Fábio Ramos (secretário) e Asdrubal Augusto do Nascimento (gerente). O primeiro conselho fiscal foi composto por Antônio Zerrenner, Dr. Paulo Ferreira Alves e Dr. Augusto de Siqueira Cardoso (BRASIL, 1891).

12 Apesar do controle da empresa por Zerrenner e Büllow, o presidente a partir de 1894 foi Asdrubal 
Antarctica à beira da insolvência em 1893, com redução de seu capital para 1.710 contos de réis. A empresa se expandiu no restante da década (KÖB, 2000, p. 38; SUZIGAN, 2000, p. 231-232; MARSON, 2017, p. 60). ${ }^{13}$

De acordo com Bandeira Júnior (1901), até o início do século XX a companhia já contava com três máquinas de gelo, duas do sistema Lind e uma americana do modelo Cleveland. A capacidade da produção de cerveja poderia chegar a 42.000 litros em 24 horas e o volume de gelo fabricado poderia atingir 58.000 quilos no mesmo intervalo (BANDEIRA JÚNIOR, 1901, p. 35-36).

No setor cervejeiro, a capacidade de produção tinha elevado grau de concentração, evidenciando características oligopolistas já em 1907. Nesse sentido, 15 das maiores fábricas do segmento geravam aproximadamente $75 \%$ da produção total no ano. Dentre elas, as três empresas de maior porte eram a Companhia Cervejaria Brahma, a Companhia Antarctica Paulista e a Fábrica de Cerveja Paraense. Essa estrutura de mercado concentrada já começou a ser formada em 1890, a partir da abertura dessas grandes cervejarias, de maneira que "[...] as três companhias controlavam mais de $50 \%$ do mercado, $61,9 \%$ do capital, $68 \%$ da potência instalada e $47,3 \%$ da mão de obra empregada na indústria de cerveja [em 1907]. Mas a Brahma e a Antarctica tinham predomínio absoluto [...]" (SUZIGAN, 2000, p. 235).

Nos primeiros anos do século XX, foram observados o aumento acelerado no consumo de cerveja e a ampliação do mercado interno. Assim, houve a crescente necessidade de expansão no nível de produção das indústrias de bebidas. "A Antarctica e a Brahma, especialmente, ampliaram as instalações, diversificando a produção para incluir bebidas não alcoólicas, soda, gelo, ácido carbônico, etc." (SUZIGAN, 2000, p. 235-236).

A próxima seção busca mostrar quais foram as fontes de recursos que permitiram o investimento na expansão da Companhia Antarctica Paulista no período.

Augusto do Nascimento (SÃO PAULO, 10/02/1895). O sr. Adam von Bülow assumiu a presidência interina da empresa em meados de 1908, mas já no final desse ano Asdrubal Nascimento assinou o balanço da companhia. Bülow permanecerá como diretor até seu falecimento em maio de 1923 (SÃ̃ PAULO, 20/03/1909, p. 927-929; 09/03/1924, p. 2045) Asdrubal Nascimento permanecerá na presidência da Companhia até 1925 (falece em 1926), quando é assumida por Antônio Zerrenner, sendo o conselho fiscal composto por William Nielsen, Antônio Prado e William J. Scheldon (SÃO PAULO, 18/03/1926, p. 2269). Antônio Zerrenner ficou na presidência da Antarctica até seu falecimento, em setembro de 1933. Em 1934, assinou como presidente interino da empresa C. A. von Bülow. Em 1935, o presidente em exercício era Antônio Bento Vidal, mas, já a partir de 1937, Bülow voltou a exercer o cargo, permanecendo até pelo menos o início dos anos 1940 (SÃO PAULO, 25/03/1934, p. 34; 24/03/1935, p. 30; 25/03/1938, p. 54; 21/03/1941, p. 55).

13 Fica claro pela análise dos relatórios da Antarctica que não apenas o controle da empresa foi restrito a um grupo de pessoas, mas também o próprio conjunto de seus acionistas. Por exemplo, conforme na Ata da Assembleia Geral Extraordinária de 19 de junho de 1919, estavam reunidos 14 acionistas (entre eles, Asdrubal do Nascimento, Adam von Bülow, William Nielsen, Eduardo Freire, Zerrenner Bülow $\mathcal{J}$ Comp., Eise von Hardt, R. H. von Bülow, C. A. von Bülow, C. M. Bertoni, Karl Bertoni, Hanne Jensen, Antônio Zerrenner, Madeleine Martin) possuidores de 78,5\% (50.018 de 63.750) das ações emitidas (SÃO PAULO, 27/06/1919, p. 3902-3903). 


\section{As Fontes de Financiamento da Companhia Antarctica Paulista}

O desempenho de longo prazo de uma empresa produtora de cerveja no Brasil no final do século XIX e início do século XX dependia da sua capacidade de acesso a financiamento, já que para o empreendimento era necessário alto investimento em capital fixo, com a aquisição de máquinas a vapor e de gelo, armazéns refrigerados e rede de distribuição do produto (KÖB, 2000, p. 39). Para o estudo das origens das fontes de financiamento direcionadas à Companhia Antarctica Paulista, buscou-se a análise dos balanços patrimoniais da empresa. As demonstrações financeiras utilizadas no estudo foram publicadas pelo Diário Oficial do Estado de São Paulo (SÃO PAULO, 1890-1941) entre os anos de 1890 e 1941. Posteriormente, os dados encontrados, referentes às contas do ativo e passivo da companhia para cada ano, foram transferidos e organizados em uma planilha (ver Anexo A).

De maneira especial, a análise da estrutura do passivo permitiu rastrear a evolução do nível de participação das fontes de financiamento no provimento de recursos para a companhia ao longo do período. Desse modo, suas contas foram classificadas em seis grupos: mercado de capitais (que inclui fundos provenientes de ações e debêntures); empréstimos bancários; títulos hipotecários; fornecedores; capital próprio; e outras fontes não especificadas. A partir da divisão do valor referente a cada conjunto de contas pelo passivo total, foi possível calcular a participação proporcional de cada fonte de recurso nos fundos disponíveis para a empresa.

Os valores do ativo total da Companhia Antarctica Paulista foram obtidos, originalmente, a preços correntes. Portanto, para que a análise não sofresse distorções que pudessem superestimar o aumento de ativos da companhia, foi necessário deflacionar a série de dados. Para estabelecer os valores do ativo real a preços de 1913, escolhido como o ano-base, foram utilizados os seguintes índices de preço: de 1891 a 1913 (CATÃO, 1992, p. 530) e de 1913 a 1930 (MALAN et al., 1977, p. 516).

Com base nessa análise, foi observado que os recursos da companhia vieram de diferentes fontes. No entanto, o nível de participação entre elas variava de maneira considerável ao longo dos anos. Pela análise do Gráfico 1, fica claro que, nos primeiros anos de operação da companhia, os recursos provenientes do mercado de ações e debêntures perfaziam quase a totalidade dos fundos da empresa, correspondendo a 93,8\% de seu capital no ano de 1891. Nesse sentido, o aumento da proteção dos acionistas e credores, estabelecida no estatuto das empresas, seria uma das razões pelas quais companhias como a Antarctica conseguiram obter grande aporte de recursos junto aos investidores (MUSACCHIO, 2009, p. 39; HANLEY, 2005, p. 117). Entre 1889 e 1901, ocorreu um aumento significativo do capital da empresa de 3.500 contos para 7.000 contos de réis, realizado com a emissão de ações, elevando a participação relativa do mercado de capital no financiamento das atividades da empresa de 57\% para 73\% (ver Gráfico 1). O mercado de capitais 
(ações e debêntures) representava cerca de 60\% das fontes de financiamento entre 1904 e 1909, quando caiu para 47\% em 1911. Em 1913, diante da necessidade de expansão das atividades da companhia, sua diretoria foi autorizada a contrair um empréstimo de 6.000 contos de réis (dois milhões de dólares), o qual foi realizado com a emissão de debêntures, ${ }^{14}$ que explica, com a alteração do capital social de 8.500 contos de réis, em 1913, para 12.750 contos de réis, em 1914, o aumento da participação do mercado de capitais de $55 \%$ das fontes de financiamento, em 1913, para 68,5\% em 1915, conforme o Gráfico 1 e o Anexo A (BRASIL, 1913; SUZIGAN, 2000, p. 236, nota 337). Entretanto, após essas oscilações, essa modalidade de financiamento começou a perder participação após 1915, no contexto da Primeira Guerra Mundial. A partir desse ano, os recursos derivados de ações e debêntures caíram para 55,5\% em 1918, último ano do conflito. A partir dessa perspectiva, é oportuno observar que os anos de protagonismo desses títulos no financiamento da Antarctica, convergem exatamente com o período de maior crescimento do mercado de capitais, identificados no estudo de Hanley (2005) e Musacchio (2009).

Gráfico 1 - Origem das fontes de financiamento da Companhia Antarctica Paulista entre os anos de 1891 e 1940 (em \% dos recursos totais)

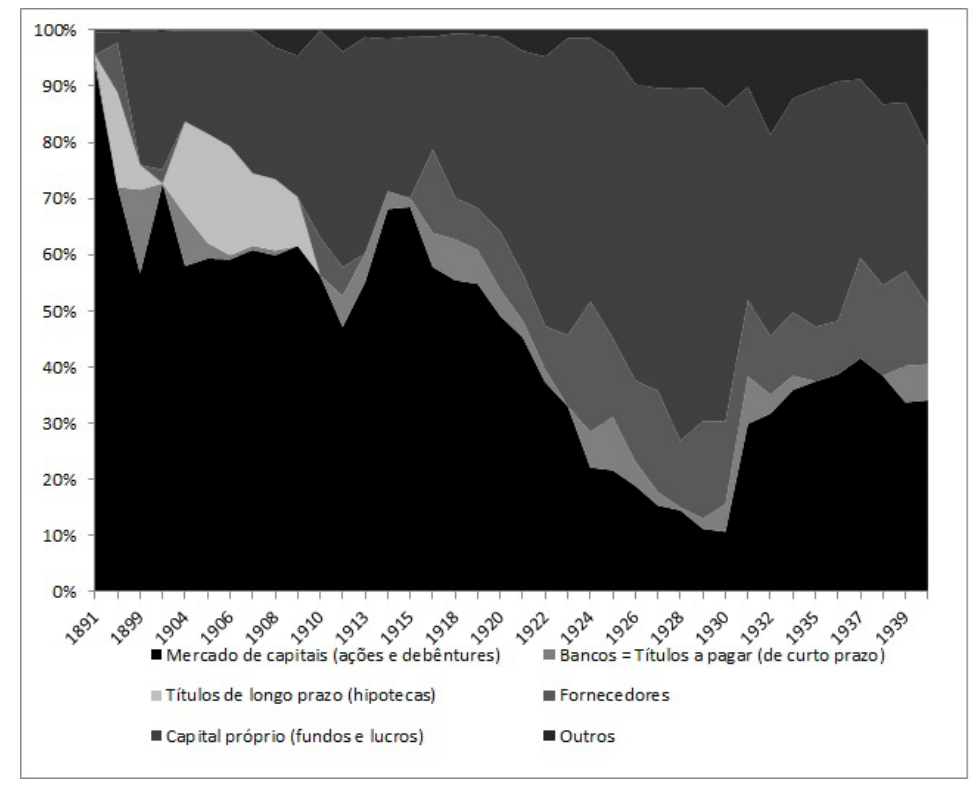

Fonte: Elaboração própria a partir dos balanços patrimoniais da empresa publicados no período (ver Anexo A).

14 O intermediário na subscrição desse empréstimo via debênture foi o banco Brasilianischen Bank für Deutschland (MARQUES, 2014, p. 93; SÃO PAULO, 27/03/1913, p. 1403). 
É oportuno ressaltar que, a partir de 1915, observou-se a queda persistente na participação relativa de financiamento por meio do mercado de capitais (ações e títulos) para a empresa. Essa queda da proporção relativa ocorreu porque a empresa manteve o mesmo capital nominal de 12.750 contos entre 1914 e 1930, em um contexto de crescimento do ativo total, com financiamento principalmente por fundos de reservas e lucros retidos (ver Gráfico 1 e Anexo A). A modalidade de financiamento por mercado de capitais alcançou um de seus menores níveis de participação no período da crise de 1929, quando atingiu $11,2 \%$ das fontes de financiamento. O episódio, marcado pela queda repentina das ações na Bolsa de Nova York, afetou o mercado de capitais, contribuindo para seu declínio no país. Em 1930, a participação relativa de ações e debêntures atingiu apenas 10,7\% dos recursos totais ofertados à empresa. A proporção desse tipo de financiamento voltou a aumentar no ano seguinte, atingindo o pico de 41,6\% do total em 1937. A explicação para esse aumento na participação relativa do mercado de capitais (ações e debêntures) nos anos 1930 é o aumento do capital social da empresa de 12.750 contos, em 1930, para 31.875 contos, em 1931, o qual permanece até 1940 e os novos financiamentos com empréstimos pela emissão de debêntures ${ }^{15}$ ao longo da década de 1930. No entanto, sua relevância não chegou a representar os altos níveis observados no período inicial de operações da companhia.

Dentre os bancos que ofereceram empréstimos à companhia, apareceram em alguns balanços ${ }^{16}$ a Banca Francesa e Italiana, o The National City Bank of New-York e a Caixa Econômica Federal de São Paulo. No entanto, como pode ser observado no Gráfico 1, empréstimos bancários não apresentaram grande representatividade no financiamento da empresa no intervalo analisado. Com base nos dados do período, para quase toda a série, a proporção desse tipo de empréstimo se manteve abaixo dos $10 \%$ das fontes de financiamento. O maior nível de participação foi observado em 1899, quando essa modalidade chegou a representar 14,9\% dos recursos da empresa. A crise da década de 1930 parece não ter contribuído de maneira significativa para a queda da proporção dessa fonte de financiamento, a qual chegou até a aumentar, partindo de 4,9\%, em 1930, para 8,5\% em 1931. Entretanto, a participação dos bancos foi nula entre 1935 e 1938, voltando a subir para 6,5\%, em 1939, e mantendo-se nesse patamar em 1940. Essa constatação parece reforçar a observação de que os bancos adotaram um comportamento mais conservador em relação ao fornecimento de empréstimos de longo prazo à indústria, pelo menos para empresas sociedades anônimas que tinham acesso a

15 Na assembleia extraordinária de 25 de agosto de 1931, foi aprovado o lançamento de empréstimo de 20.000 contos de réis por debêntures que seriam emitidos ao longo da década de 1930 (SÃO PAULO, 24/03/1932, p. 19).

16 O empréstimo da Banca Francesa e Italiana apareceu no balanço patrimonial de 1911 a 1914, o do The National City Bank of New-York, no ano de 1915 e o da Caixa Econômica Federal de São Paulo, nos anos de 1939 e 1940. 
outras formas de financiamento, como o mercado de capitais. Dessa maneira, estariam mais focados em empréstimos de curto prazo e financiamentos do complexo exportador cafeeiro em detrimento do setor industrial ${ }^{17}$ (MUSACCHIO, 2009, p. 62). Nesse ponto, o caso da Companhia Antarctica parece convergir com a condição da cervejaria Brahma, em que os bancos alemães parecem não ter mostrado muito interesse no fornecimento direto de crédito para projetos industriais, mas intermediários de emissões de debêntures (MARQUES, 2005, p. 102-103).

Como pode ser observado no Gráfico 1, os empréstimos hipotecários tiveram considerável participação nos primeiros anos da Companhia Antarctica Paulista. Essa modalidade de crédito chegou a representar 19,4\% das fontes de recursos da empresa nos anos de 1905 e 1906. As contas do passivo nos balanços observados não mostraram mais indícios de participação do crédito hipotecário para o financiamento da Antarctica a partir de 1910. Não obstante, é oportuno observar que, no período no qual se apresentou, essa fonte de crédito revelou proporcionalmente maior participação no fornecimento de recursos se comparado àqueles fornecidos via empréstimos bancários.

Na década de 1920, pelas informações do Gráfico 1, é possível observar uma mudança na origem principal de recursos que ofereceram suporte para os investimentos da Companhia Antarctica. O mercado de ações e títulos deixou de ser o protagonista no aporte de capital para a empresa e, em 1922 os recursos próprios passaram a ser sua principal fonte de financiamento. No mesmo ano de 1922, as reservas e os lucros acumulados corresponderam a $48 \%$ dos fundos disponíveis, contra $37,3 \%$ do mercado de capitais, que passou para o segundo lugar. Por outro lado, o Gráfico 2 mostra que, entre as décadas de 1920 e 1930, ocorreu o aumento do ativo da empresa, que atingiu o pico de 63.645 contos de réis, em 1930, a preços de 1913. Como pode ser observado de maneira paralela no Gráfico 1, esse crescimento passou a ser financiado predominantemente pelos lucros e fundos da própria companhia, os quais chegaram a representar mais de 50\% dos recursos da empresa entre os anos de 1925 e 1930. Conforme comentado anteriormente, o mercado de capitais voltou a ter a maior participação relativa somente em 1937, representando $41,6 \%$ dos recursos totais, no entanto em proporções bastante inferiores àquelas observadas entre as décadas de 1890 e 1900, quando sua participação chegou a superar $90 \%$ do capital da companhia.

17 Entretanto, Marson (2019) mostra que os bancos foram importantes para o financiamento de outros tipos de empresas industriais em sociedade, como a sociedade em comandita, sociedades em nome coletivo ou com firma, sociedades de capital e indústria e a sociedade em conta de participação. 
Gráfico 2 - Evolução do ativo da Companhia Antarctica Paulista entre os anos de 1891 e 1940 (em contos de réis)

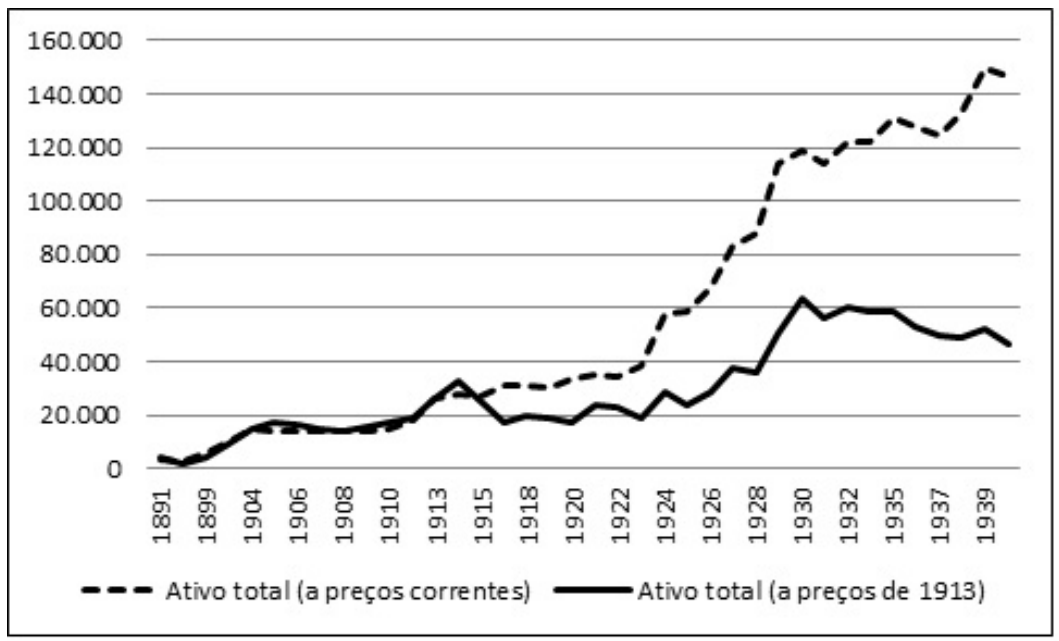

Fonte: Elaboração própria a partir dos balanços patrimoniais da empresa publicados no período (ver Anexo A).

Pela análise do Gráfico 2 é possível perceber os principais períodos de maior crescimento do ativo da Antarctica. Houve um significativo crescimento do ativo real da companhia entre 1899 e 1905. Nesse período, a Antarctica aumentou seu capital de 3.500 contos, em 1899, para 7.000 contos, em 1901, e para 8.500 contos de réis em 1904. Nesse último ano, a empresa comprou a sua concorrente no mercado paulista, a Bavária, ${ }^{18}$ por 3.700 contos de réis (KÖB, 2000, p. 38; SUZIGAN, 2000, p. 232). Houve estabilização no crescimento do ativo da companhia entre 1906 e 1910 e um novo forte crescimento entre 1911 e 1914, com a constituição e expansão da sua cervejaria em Ribeirão Preto, interior de São Paulo, conforme o Anexo A e Kob (2000, p. 38). A Primeira Guerra Mundial dificultou as atividades da Antarctica, já que a evolução do seu ativo real caiu significativamente durante o conflito, não recuperando o patamar do seu ativo anterior ao conflito até 1927. Ao descrever a crise, no relatório de março de 1918, os diretores ressaltam os efeitos da greve, da guerra europeia, que dificultava a importação de matéria-prima e sua consequente elevação de preço, e da elevação dos impostos como razão das dificuldades internas do país (SÃO PAULO, 26/03/1918, p. 1953). Os dois

18 A compra da Bavária de Heinrich Stupakoff, fundada em 1892, a segunda maior cervejaria de São Paulo, pela Antarctica, fazia parte inicialmente de um projeto de grande acordo no final de 1901 entre as principais cervejarias brasileiras para domínio e repartição do mercado nacional. A frustação desse acordo a nível nacional resultou na divisão regionalizada do mercado, ficando a Antarctica com São Paulo, já que a Bavária era sua única real concorrente no mercado paulista (MARQUES, 2014, p. 78-87). 
anos iniciais da década de 1920 não foram favoráveis para a evolução do ativo da Companhia Antarctica Paulista. A Antarctica anunciou, no relatório da diretoria de 1922, novos investimentos em obras de expansão nas fábricas da Mooca, Ribeirão Preto e Bauru, que serão concretizados no ativo a partir de 1923 (SÃO PAULO, 18/03/1923, p. 2144, 09/03/1924, p. 2045; Anexo A) A empresa também adquiriu a maioria das ações da Cervejaria Polar, de Belo Horizonte, e o acervo da fábrica Polarctica, da Bahia, em 1927, aparecendo no ativo da empresa a partir de 1928 (SÃO PAULO, 15/03/1928, p. 2309). Em 1928, a companhia anunciou a aquisição do acervo da Cervejaria Pernambucana, de Recife (SÃO PAULO, 28/03/1929, p. 3019). No relatório da diretoria de 1929 , a Antarctica relatou que tinha filiais ${ }^{19} \mathrm{em}$ Ribeirão Preto, Santos, Bauru, Rio de Janeiro, Belo Horizonte, Recife e Salvador (SÃO PAULO, 25/03/1930, p. 2933). Apesar de forte crescimento do ativo real da Antarctica no final da década de 1920 (entre 1924 e 1930), a crise de 1929 e a posterior Grande Depressão dos anos 1930 impactaram negativamente nas atividades da empresa. Assim, entre 1931 e 1932 a Antarctica fechou as filiais da Bahia e Bauru pelos constantes prejuízos (SÃO PAULO, 25/03/1934, p. 34). Os negócios da empresa se recuperam a partir de 1933, com a expansão da filial no Rio de Janeiro na metade final dos anos 1930 (SÃO PAULO, 21/03/1940, p. 54). Entretanto, até 1940 a Antarctica não irá voltar a ter o mesmo nível de ativo, em termos reais, do ano de 1930.

Outro aspecto interessante de análise é a evolução da participação de capitais de terceiros e próprio no ativo total da empresa, o qual é apresentado no Gráfico 3. Em relação à composição da origem de seu capital, é possível notar a importância da participação de recursos próprios da Companhia Antarctica Paulista no ativo total. Conforme pode ser observado no Gráfico 3, essa parcela se sustentou acima de $60 \%$ em quase todo o período analisado, apresentando maior sinal de queda após 1936. Ao final da série, após 1938, a proporção de capital de terceiros ultrapassou a participação do capital próprio, ocupando 51,61\% do ativo total.

19 É interessante destacar que a Antarctica foi pioneira em construir filiais em mercados regionais fora de sua sede. A Brahma, sua principal concorrente, instalou sua primeira fábrica fora da sede (Rio de Janeiro) apenas no início dos anos 1960, no Recife (MARQUES, 2014, p. 93). 
Gráfico 3 - Composição do capital (entre terceiros e próprio) da Companhia Antarctica Paulista: 1891-1940 (em \%)

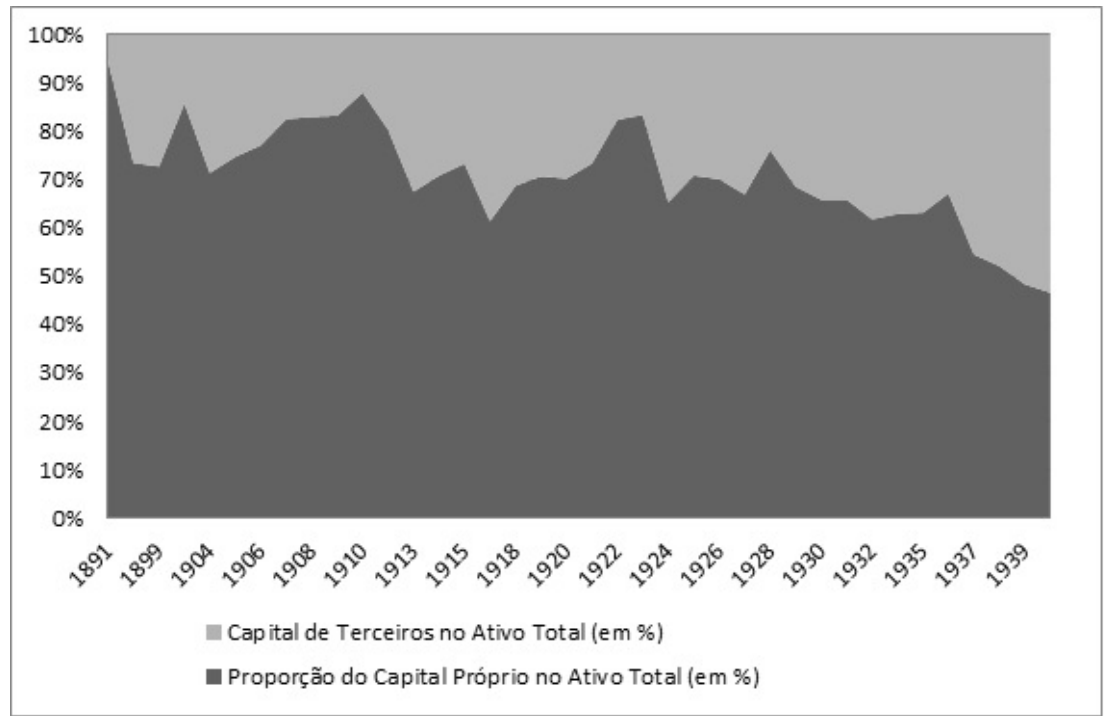

Fonte: Elaboração própria a partir dos balanços patrimoniais da empresa publicados no período (ver Anexo A).

\section{Considerações Finais}

No decorrer do estudo, buscou-se observar o nível de participação das principais fontes de recursos no financiamento da Companhia Antarctica Paulista. Dessa forma, os dados referentes aos balanços patrimoniais da empresa entre os anos de 1891 e 1940 foram organizados e analisados conforme a sua evolução.

Ao final do trabalho, foi possível concluir que a origem dos recursos que permitiram a expansão da companhia estava concentrada no mercado de capitais, em fundos e lucros da própria empresa. Nesse sentido, observou-se que o mercado de capitais se apresentou como uma importante fonte de financiamento nos primeiros anos da Antarctica. Dessa maneira, com exceção de 1911, no período entre 1891 e 1920 as ações e títulos respondiam por pelo menos 50\% da participação na origem de recursos da companhia. Essa situação só se inverteu na década de 1920, quando a Antarctica passou a se financiar majoritariamente pelos seus próprios lucros e reservas. O mercado de capitais só voltou a apresentar maior participação relativa em 1937, quando representou 41,6\% dos recursos totais. Embora sua participação voltasse a crescer após 1937, o financiamento por meio de ações e títulos não chegou a alcançar os níveis relativos que apresentou em seus primeiros anos de expansão. 
Os empréstimos bancários não tiveram uma presença expressiva no período analisado, de modo que o nível de sua participação relativa no financiamento da companhia não ultrapassou $10 \%$ do total de recursos disponíveis na maioria dos anos. Em algumas demonstrações mais detalhadas, nas contas do balanço patrimonial da companhia, foi possível identificar recursos advindos da Banca Francesa e Italiana, do The National City Bank of New-York e da Caixa Econômica Federal de São Paulo. Nesse sentido, um dos indicadores da baixa participação dos bancos no aporte de recursos para a empresa foi a grande proporção de capital próprio em seu patrimônio, o qual chegou a representar mais de $80 \%$ do seu ativo total em alguns anos.

A partir da análise do caso da Companhia Antarctica Paulista, foi possível observar a relevância do mercado de capitais nos primeiros anos da companhia. Essa forma de financiamento ofereceu o impulso inicial para os investimentos necessários à empresa em um período ainda incipiente do desenvolvimento industrial e financeiro de São Paulo. As evidências encontradas neste trabalho parecem convergir com a conclusão do estudo de Hanley (2001), Hanley (2005) e Musacchio (2009) sobre o papel da bolsa de valores no financiamento de empresas paulistas entre 1886 e 1917. Nesse sentido, o curto período de expansão do mercado de títulos e ações foi suficiente para a consolidação inicial e o crescimento de empresas como a Antarctica no mercado brasileiro. Dessa maneira, ainda que a bolsa não tenha obtido sucesso em se sustentar no decorrer dos anos, apresentou uma contribuição significativa no desenvolvimento econômico de longo prazo (HANLEY, 2001, p. 140-141).

\section{Referências}

\section{FONTES PRIMÁRIAS}

BRASIL, 1891. Decreto n ${ }^{\circ} 217$, de 2 de maio de 1891.

BRASIL, 1913. Decreto no 10.036, de 6 de fevereiro de 1913.

SÃO PAULO. Diário Oficial do Estado de São Paulo, 1890-1941.

BANDEIRA JR., A. F. A indústria no estado de São Paulo em 1901. Typ. do" Diario Official”, 1901, p. 35-36.

\section{FONTES SECUNDÁRIAS}

BAER, W. A industrialização e o desenvolvimento econômico do Brasil. Rio de Janeiro: Fundação Getúlio Vargas, 1966.

BECK, T.; DEMIRGÜÇ-KUNT, A.; LEVINE, R. A new database on financial development and structure. The World Bank Policy Research Working Paper, n. 2146, 1999. 
BECK, T.; LEVINE, R.; LOAYZA, N. Finance and the sources of growth. Journal of Financial Economics, n. 58, 2000.

BRITO, J. R. A economia brasileira no alvorecer do século XIX. Salvador: Progresso, 1923, p. 107.

CANO, W. Raízes da concentração industrial em São Paulo. 1975. Tese (Doutorado) - UNICAMP, Campinas, 1975.

CANO, W. Desequilíbrios regionais e concentração industrial no Brasil: 1930-1970. São Paulo: Global; Campinas: Editora da Universidade Estadual de Campinas, 1985.

CATÃO, L. A. V. A new wholesale price index for Brazil during the period 1870-1913. Revista Brasileira de Economia, v. 46, n. 4, p. 530, 1992.

CORTES, G. S.; MARCONDES, R. L.; DIAZ, M. D. M. Mortgages for machinery: credit and industrial investment in pre-world war i Brazil. Financial History Review, v. 21, n. 2, p. 191212, 2014.

DEAN, W. A industrialização de São Paulo. São Paulo: Difel, 1971.

DEMIRGÜÇ-KUNT, A.; LEVINE, R. Financial structure and economic growth: a cross-country comparison of banks, markets, and development. Cambridge: The MIT Press, 2001.

FISHLOW, A. Origens e consequências da substituição de importações no Brasil. Estudos Econômicos. São Paulo, v. 2, n. 6, 1972.

FOHLIN, C. Mobilizing money: how the world's richest nations financed industrial growth. New York: Cambridge University Press, 2012.

FOHLIN, C. Financial systems and economic development in historical perspective, In: DIEBOLT, C.; HAUPERT, M. (ed.). The handbook of cliometrics. Berlin: Springer Verlag, 2016.

GAMBACORTA, L.; YANG, J.; TSATSARONIS, K. Financial structure and growth. BIS Quarterly Review, mar. 2014.

GERSCHENKRON, A. Economic backwardness in historical perspective: a book of essays. Cambridge: The Belknap Press of Harvard University Press, 1962.

GOLDSMITH, R. W. Financial structure and development. New Haven: Yale University, 1969.

HABER, S. Business enterprise and the great depression in Brazil: a study of profits and losses in textile manufacturing. Business History Review, n. 66, p. 335-363, 1992.

HABER, S. Financial markets and industrial development: a comparative study of governmental regulation, financial innovation, and industrial structure in Brazil and Mexico, 18401930. In: HARBER, S. How latin america fell behind. Stanford, California: Stanford University Press, 1997, p. 149-150.

HANLEY, A. A bolsa de valores e o financiamento de empresas em São Paulo, 1886-1917. História Econômica 8 História de Empresas, v. 4, n. 2, p. 115-142, 2001. 
HANLEY, A. Is it who you know? Entrepreneurs and bankers in São Paulo, Brazil, at the turn of the twentieth century. Enterprise 8 Society, v. 5, n. 2, p. 187-225, 2004.

HANLEY, A. Native capital: financial institutions and economic development in São Paulo, Brazil, 1850-1920. Stanford: Stanford University Press, 2005, p. 116-117.

KÖB, E. Como a cerveja se tornou bebida brasileira: a história da indústria de cerveja no Brasil desde o início até 1930. Revista do Instituto Histórico e Geográfico Brasileiro, v. 161, n. 409, p. 29-58, 2000.

LAGO, L. A. C.; ALMEIDA, F. L.; LIMA, B. M. F. A indústria brasileira de bens de capital: origens, situação recente e perspectivas. Rio de Janeiro: FGV:IBRE, 1979. p. 15.

LAW, S. H.; SINGH, N. Does too much finance harm economic growth? Journal of Banking E Finance, v. 41, 2014.

LEVINE, R.; ZERVOS, S. Stock markets, banks and economic growth. American Economic Review, v. 88, p. 537-558, 1998.

LEVINE, R.; LOAYZA, N.; BECK, T. Financial intermediation and growth: causality and causes. Journal of Monetary Economics, v. 46, 2000.

LEVY, M. B. A indústria do Rio de Janeiro através de suas sociedades anônimas. Rio de Janeiro: Editora UFRJ: Secretaria Municipal de Cultura do Rio de Janeiro, 1994.

LUZ, N. V. A luta pela industrialização do Brasil, 1808 a 1930. São Paulo: Difusão Europeia do Livro, 1961.

MALAN, P. S.; BONELLI, R.; ABREU, M. P.; PEREIRA, J. E. C. Política econômica externa e industrialização no Brasil (1939-1952). Rio de Janeiro: IPEA: INPES, 1977, p. 516.

MARCONDES, R. L.; HANLEY, A. G. Bancos na transição republicana em São Paulo: o financiamento hipotecário (1888-1901). Estudos Econômicos (São Paulo), v. 40, n. 1, p. 103131, 2010.

MARCONDES, R. L. Crédito privado antes da grande depressão do século XX: o mercado hipotecário. Estudos Econômicos (São Paulo), v. 44, n. 4, p. 749-786, 2014.

MARQUES, T. C. N. Bancos e desenvolvimento econômico: uma revisão das teses de Gerschenkron à luz da Cervejaria Brahma, 1888-1917. História e Economia, v. 1, n. 1, p. 87-119, 2005 .

MARQUES, T. C. N. A cerveja e a cidade do Rio de Janeiro: de 1888 ao início dos anos 1930. Brasília: UNB; Jundiaí: Paço Editorial, 2014, p. 78-93.

MARQUES, T. C. N. A Cervejaria Brahma e os investimentos alemães no Brasil durante as duas Guerras Mundiais. História Unisinos, v. 19, p. 242-255, 2015.

MARSON, M. D. A industrialização brasileira antes de 1930: uma contribuição sobre a evolução da indústria de máquinas e equipamentos no estado de São Paulo, 1900-1920. Estudos Econômicos (São Paulo), v. 45, n. 4, p. 753-785, 2015. 
MARSON, M. D. Origens e evolução da indústria de máquinas e equipamentos em São Paulo, 1870-1960. São Paulo: Annablume:Fapesp, 2017, p. 60.

MARSON, M. D. O investimento na indústria antes de 1930: uma análise empírica com registros de empresas da Junta Comercial do Estado de São Paulo, 1911-1920. Revista Brasileira de Economia, v. 73, n. 4, p. 529-557, 2019.

MUSACCHIO, A. Experiments in financial democracy: corporate governance and financial development in Brazil, 1882-1950. Cambridge: Cambridge University Press, 2009, p. 39-67.

PRADO JR., C. História econômica do Brasil. São Paulo: Editora Brasiliense, 1959.

ROUSSEAU, P. L.; WACHTEL, P. Financial intermediation and economic performance: historical evidence from five industrialized countries. Journal of Money, Credit and Banking, v. 30, n. 4, 1998.

SAES, F.; SZMRECSÁNYI, T. El papel de los bancos extranjeros en la industrialización inicial de São Paulo. In: MARICHAL, C. Las inversiones extranjeras en América Latina, 1850-1930: nuevos debates y problemas en história económica comparada. Cidade do México: El Colegio de México, 1995, p. 240-241.

SANTOS, S. P. Os primórdios da cerveja no Brasil. Cotia: Ateliê Editorial, 2004.

SEMENICHIN, R. Breve história de uma famosa marca de cerveja. Jornal da Unicamp, ed. 327, 2006. Disponível em: http://www.unicamp.br/unicamp/unicamp_hoje/ju/junho2006/ju327pag8c.html. Acesso em: 18 mar. 2018.

SILVA, S. Expansão cafeeira e origem da indústria no Brasil. São Paulo: Alfa Omega, 1976.

SIMONSEN, R. A evolução industrial do Brasil. São Paulo: FIESP, 1939.

STEIN, S. J. Origens e evolução da indústria têxtil no Brasil, 1850-1950. Rio de Janeiro: Campus, 1979.

SUZIGAN, W. Indústria brasileira: origem e desenvolvimento. São Paulo: Hucitec, 2000, p. 228-236.

TRINER, G. D. Banking, economic growth and industrialization: Brazil, 1906-30. Revista Brasileira de Economia, v. 50, n. 1, p. 135-154, 1996.

VERSIANI, M. T. Proteção tarifária e crescimento industrial nos anos 1906/12: o caso da cerveja. Pesquisa e Planejamento Econômico, v. 12, n. 2, p. 470, 1982.

VERSIANI, F. R.; VERSIANI, M. T. A industrialização brasileira antes de 1930: uma contribuição. In: VERSIANI, F. R.; BARROS, J. R. M. (org.). Formação econômica do Brasil: a experiência da industrialização. São Paulo, 1977.

VILLELA, A. V.; SUZIGAN, W. Política do governo e crescimento da economia brasileira, 18891945. Rio de Janeiro: IPEA/INPES, 1973. 


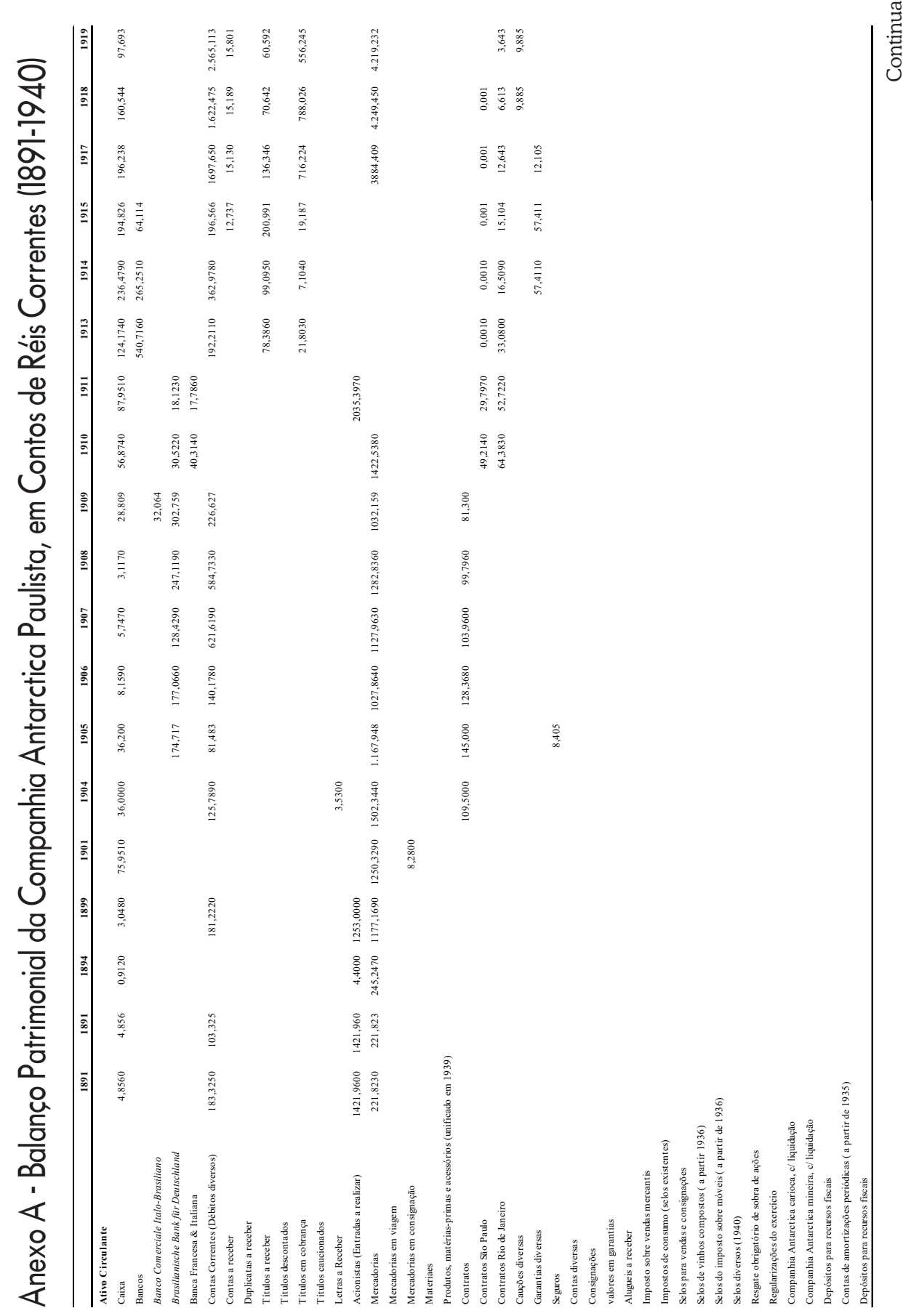




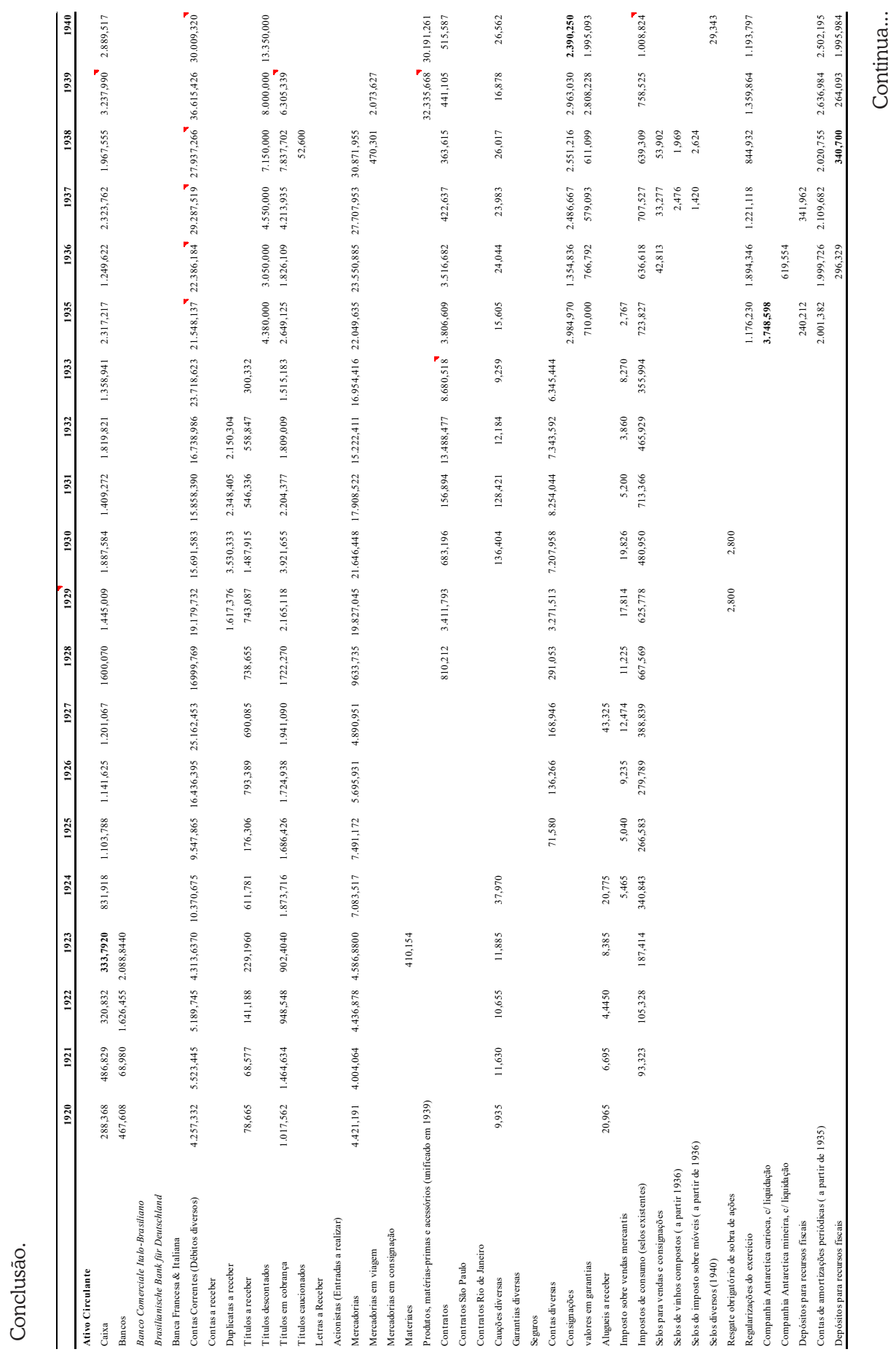




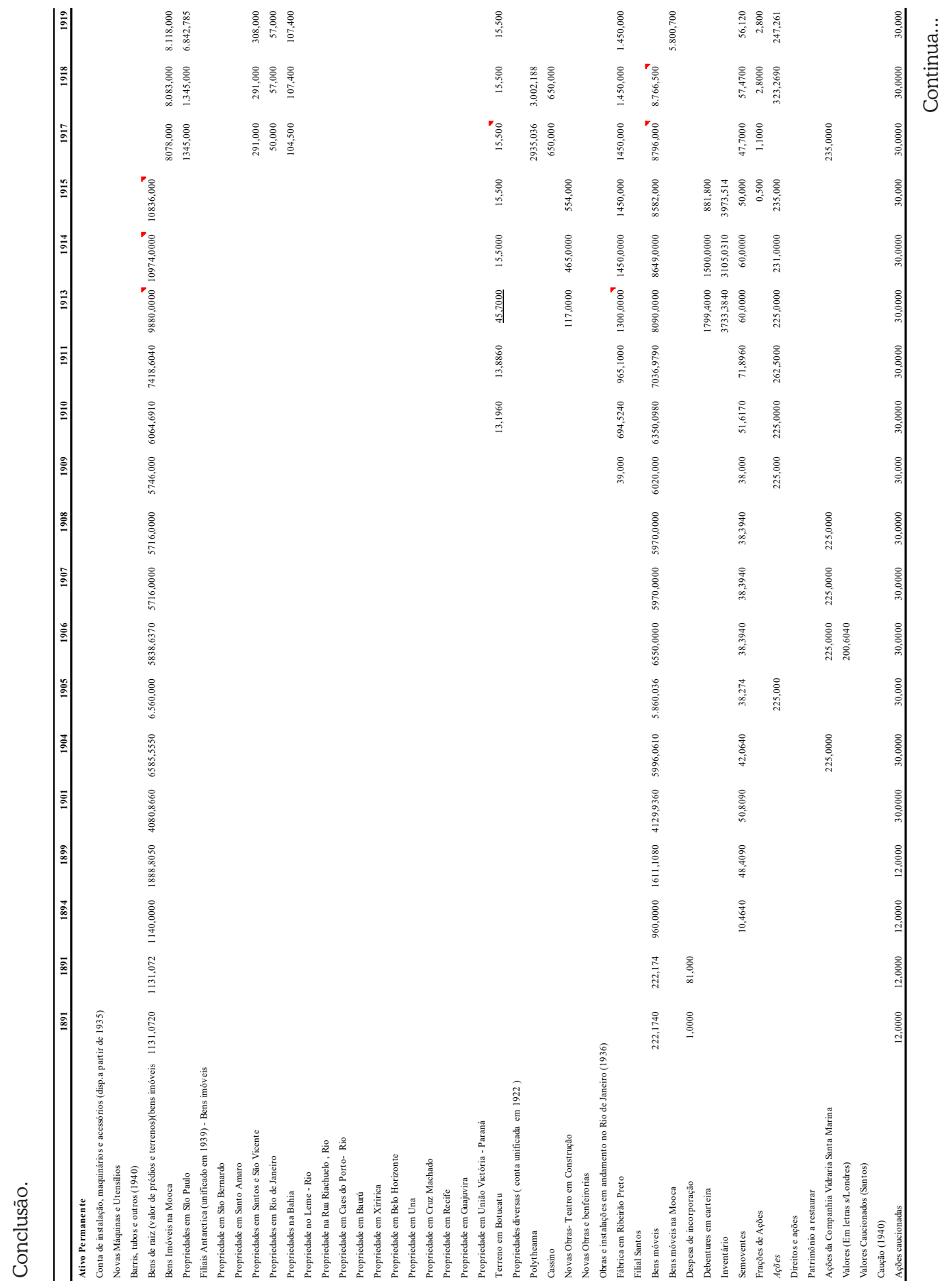




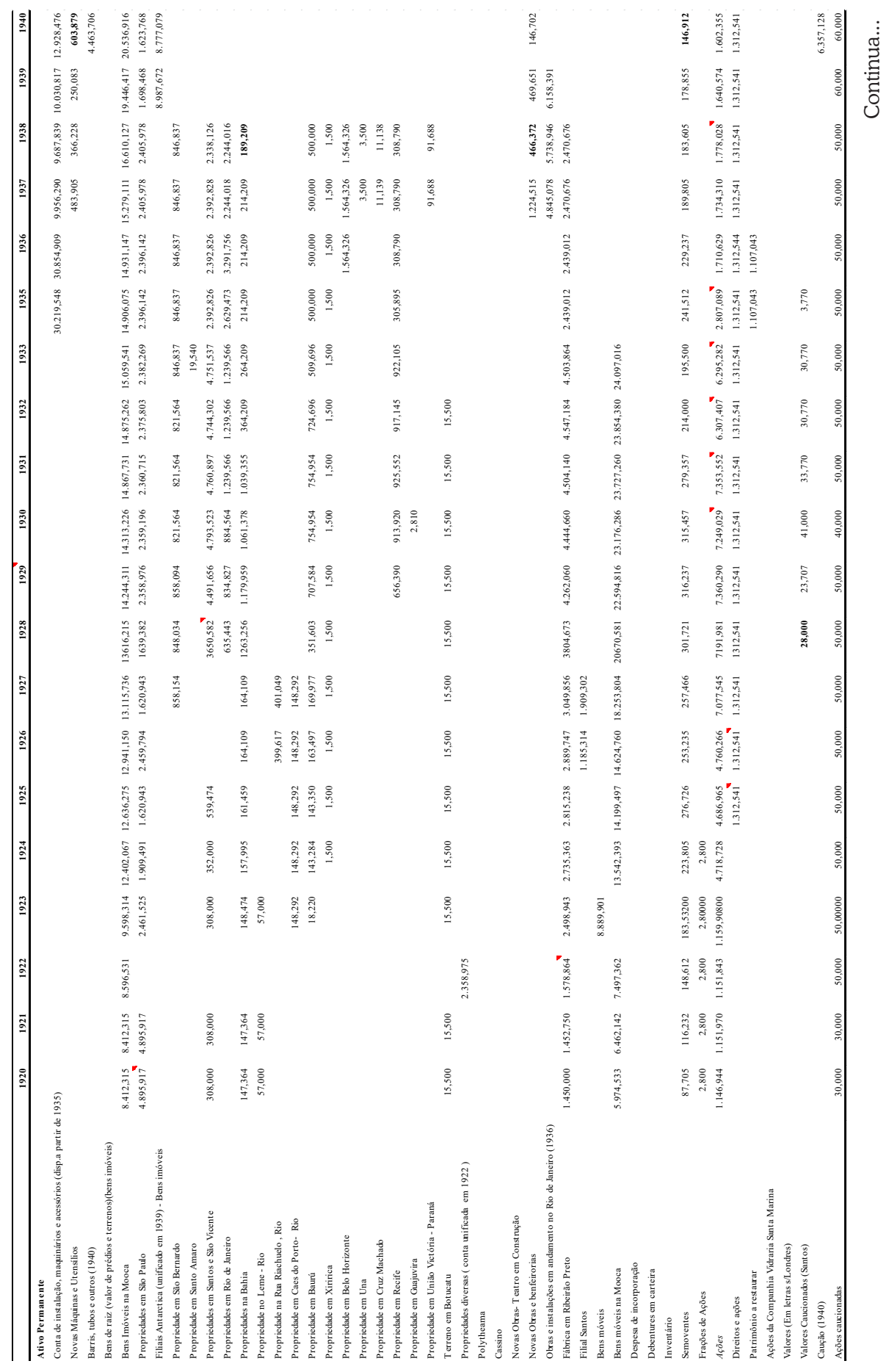




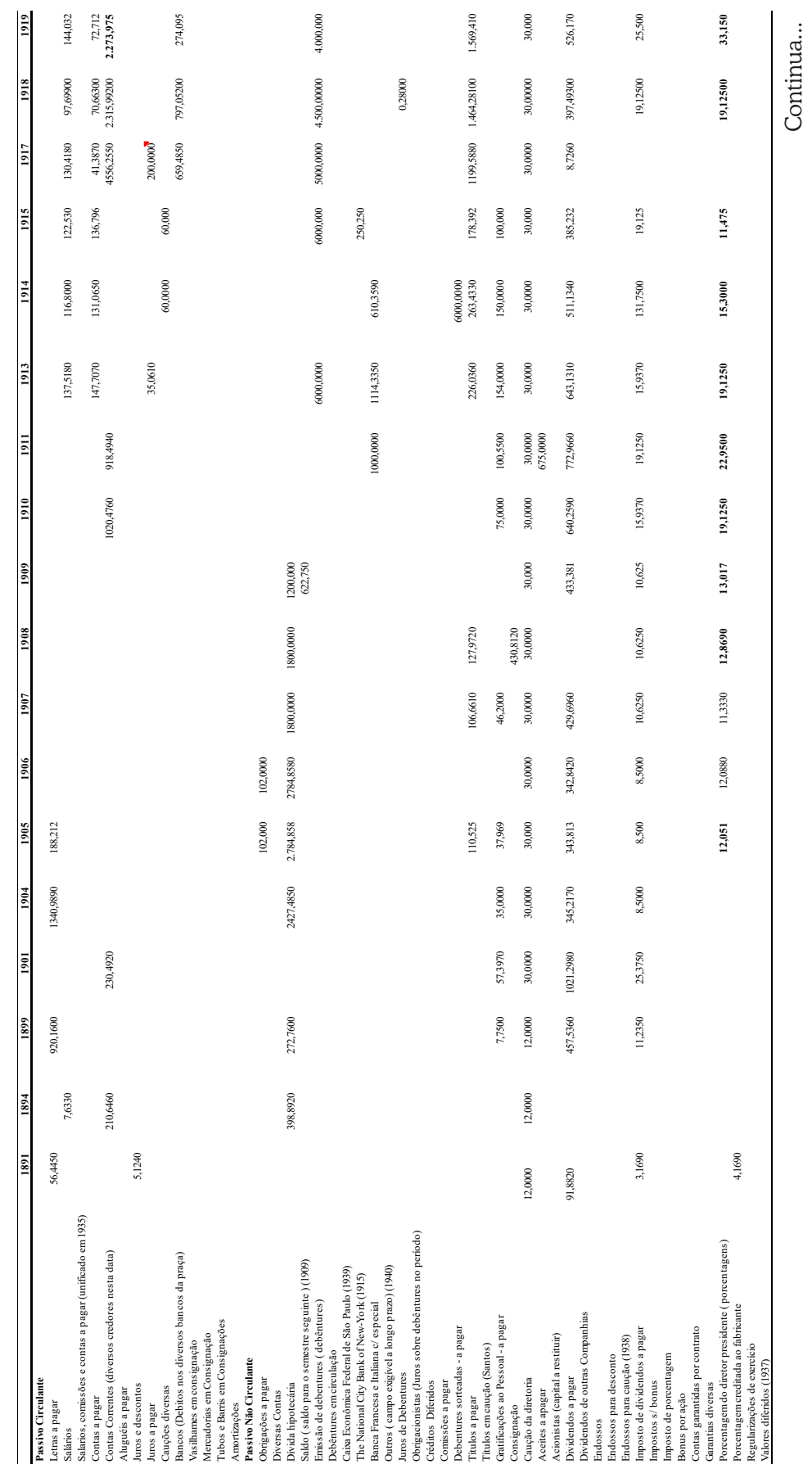




\begin{tabular}{|c|c|c|c|c|c|}
\hline 量歖 & 䜌 & 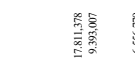 & 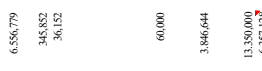 & & 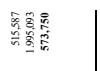 \\
\hline 喜 & 善 & 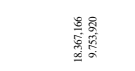 & 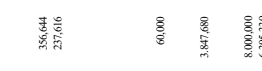 & & 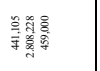 \\
\hline 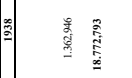 & $\frac{\circ}{2}$ & 量 & 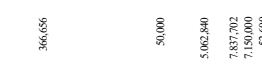 & & 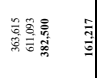 \\
\hline 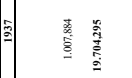 & 点 & $\frac{2}{20}$ & 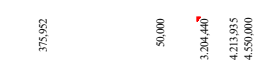 & & 等繁量 \\
\hline 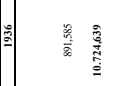 & $\frac{\alpha}{\alpha}$ & 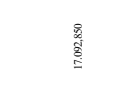 & 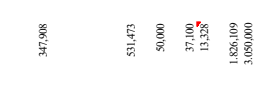 & & 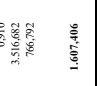 \\
\hline 憘高 & 票 & 管 & 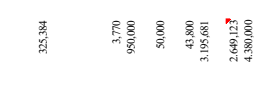 & & 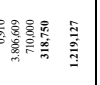 \\
\hline 害 & & 喜 & 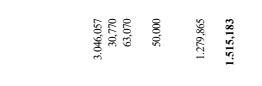 & & 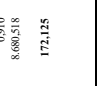 \\
\hline 泰 & & 春嘉 & 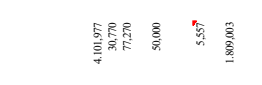 & & \\
\hline & & 帮喜 & 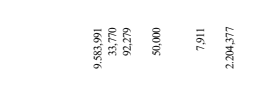 & & \\
\hline 喜 & & 愛 & 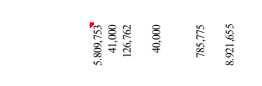 & & $\frac{2}{3}$ \\
\hline & 裹高 & 产 & 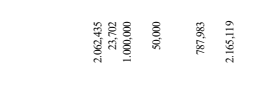 & & 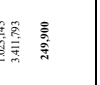 \\
\hline 墨 & & $\frac{8}{2}$ & 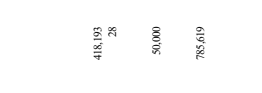 & & 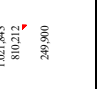 \\
\hline 㳯 & & 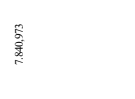 & 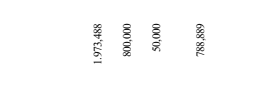 & & \\
\hline 总 & 量喜 & 餐 & 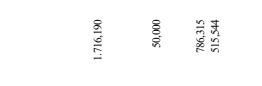 & & \\
\hline$\frac{\mathscr{v}}{\dot{z}}$ & & $\frac{8}{2}$ & 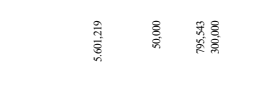 & & \\
\hline 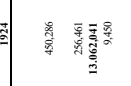 & 紗 & & 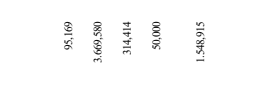 & & 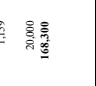 \\
\hline 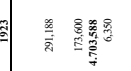 & 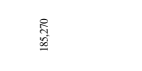 & & 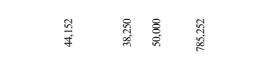 & 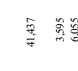 & 㩊 \\
\hline 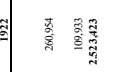 & $\stackrel{?}{=}$ & 量 & 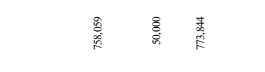 & 委采请 & $\frac{5}{2}$ \\
\hline 嘉嘉爱 & 等善 & 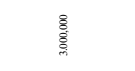 & 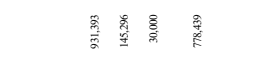 & 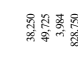 & $\frac{5}{5}$ \\
\hline 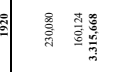 & $\frac{\mathrm{n}}{\partial \alpha}$ & 䔻 & 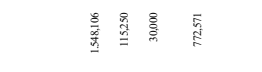 & 管 & $\frac{\hat{y}}{3}$ \\
\hline
\end{tabular}




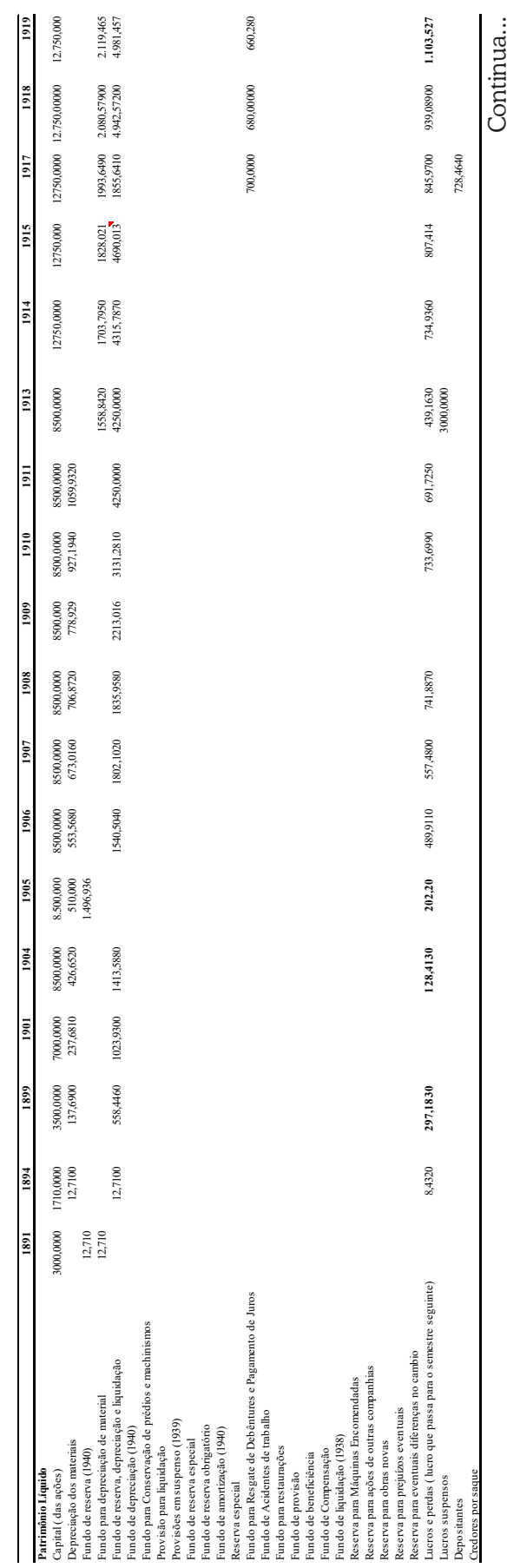




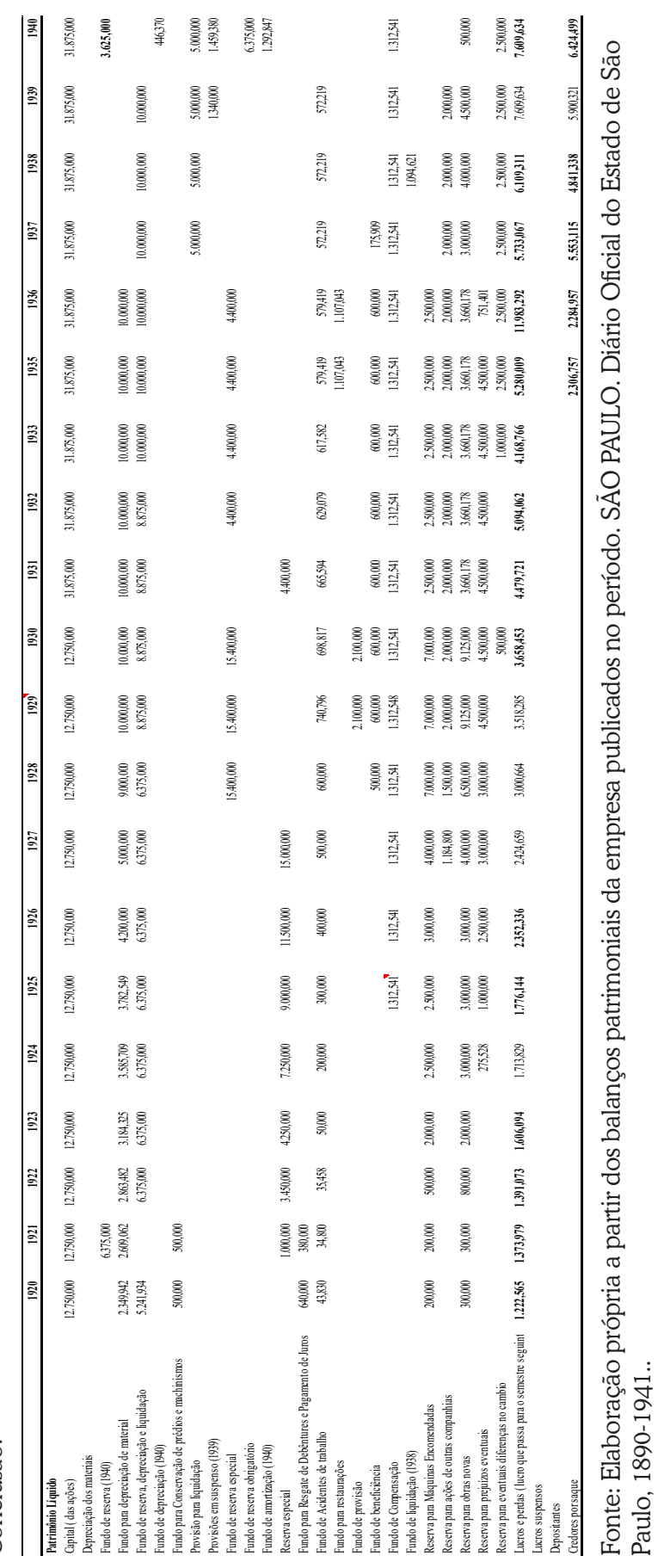




\section{Autor correspondente:}

Michel Deliberali Marson

E-mail: michelmarson@yahoo.com.br

Recebido em: 26/06/2018.

Aceito em: 29/11/2018.

(cc) BY 